\title{
Role of trace elements in animals: a review
}

\author{
Mohd Iqbal Yatoo ${ }^{1}$, Archana Saxena², Padinjare Melepad Deepa ${ }^{1}$, Biju Peer Habeab ${ }^{1}$, Sarita Devi ${ }^{3}$, \\ Ranbir Singh Jatav ${ }^{1}$ and Umesh Dimri ${ }^{1}$
}

1. Division of Medicine, Indian Veterinary Research Institue, Izatnagar, Barielly, Uttar Pradesh-243122, India;

2. Council of Scientific \& Industrial Research-Central Institute of Medicinal and Aromatic Plants, Lucknow, Uttar Pradesh226015, India; 3. College of Veterinary Science \& Animal Husbandary, Sardarkrushinagar Dantiwada Agricultural University, Dantiwada, Gujarat- 385506, India

Corresponding author: Mohd Iqbal Yatoo, email: iqbalyatoo@gmail.com

Received: 13-09-2013, Revised: 15-10-2013, Accepted: 18-10-2013, Published online: 03-12-2013

doi: 10.14202 /vetworld.2013.963-967

How to cite this article: Yatoo MI, Saxena A, Deepa PM, Habeab BP, Devi S, Jatav RS and Dimri U (2013) Role of Trace elements in animals: a review, Veterinary World 6(12): 963-967.

\begin{abstract}
Trace elements, though required in minute quantities (less than $100 \mathrm{mg} / \mathrm{kg}$ dry matter), are essential for maintaining health and immunity. They are involved in growth, production and reproduction. Trace elements act as cofactors of enzymes which are important to the immunity of animal. Superoxide dismutase, glutathione reductase, glutathione peroxidase, thioredoxin reductase, ceruloplasmin and catalase are important enzymes that have trace elements as cofactors. These enzymes act as antioxidants and prevent oxidative stress by neutralizing oxidants produced under different stresses. Besides, trace elements contribute to general health of animal thereby enhancing disease resistance. Trace elements are important for proper functioning of a number of enzymes and proteins which are involved in many physiological, biochemical and metabolic processes that contribute to growth and production. Overall, trace elements improve immune competence and productive performance.
\end{abstract}

Key words: animals, health, immunity, production, reproduction, trace minerals

\section{I ntroduction}

Trace elements are required in small amounts, usually less than $100 \mathrm{mg} / \mathrm{kg}$ dry matter [1,2] and are present in very minute quantities in animal serum [3], usually less than $2 \mathrm{ppm}$. The seven main trace elements include copper, iron, zinc, cobalt, iodine, manganese and selenium [4]. Among these, iron (1.0-2.0 ppm) is most abundant in serum followed by zinc (0.8-1.2 ppm) [4,5] and copper (0.57-1.0). On the other hand, cobalt $(1-3 \mu \mathrm{g} / \mathrm{dl})$, iodine $(2.4-14 \mu \mathrm{g} / 100 \mathrm{ml})$, manganese $(18-19 \mu \mathrm{g} / \mathrm{dl})$ and selenium $(50-220 \mathrm{ng} / \mathrm{L})$ are present in least amounts $[4,5]$. These are usually supplied via dietary intake of feeds and fodders [1]. Though required in minute amounts, they are highly essential for health and immunity [5,6]. They contribute to growth [7,8], production [7,9,10] and reproduction $[5,11]$. In particular, aspects relating to host immunity have received importance in the recent past. Trace elements act as cofactors of enzymes like superoxide dismutase (SOD) [12,13], glutathione reductase, glutathione peroxidase, thioredoxin reductase $[14,15]$, ceruloplasmin [16] and catalase [17]. These enzymes are important to maintain the immunity of animals $[7,18]$. They act as antioxidants [5,19] and prevent oxidative stress by neutralizing oxidants produced under different stresses like environmental or production stress or stress related to infections or diseases [7]. Trace elements also contribute to health and well being of animal through maintaining proper homeostatic

Copyright: The authors. This article is an open access article licensed under the terms of the Creative Commons Attribution License (http://creativecommons.org/licenses/by/2.0) which permits unrestricted use, distribution and reproduction in any medium, provided the work is properly cited. mechanisms and playing a vital role in many physiobiochemical processes like protein, enzyme and hormone synthesis $[20,21]$ or involving in oxidationreduction reactions and immune functions [22]. Trace elements are important for functioning of a number of enzymes and proteins which are essential for a large number of digestive, physiological and biosynthetic processes within the body [23]. Thus, they play a vital role in growth, production and reproduction [7,11].

\section{Health and immunity}

Trace elements are essential for health and immunity [24]. They are important for functioning of various components of the immune system [5]. Their deficiency reduces disease resistance and increases the susceptibility to diseases [18]. As they are involved in oxidation and reduction reactions through metalloenzymes and metalloproteins, their deficiency predisposes the cells to oxidative stress because oxidants are not neutralized. Oxidative stress affects animal health by damaging cells and tissues by free radicals or oxidants [7]. Uncontrolled oxidation reactions may impair the animal's immune status [25] thus lowering immunity of animals. Different immune cells and their mechanisms of phagocytic activities are affected by trace element deficiencies and hence trace element supplementation can boost immunity. For example, selenium supplementation improves neutrophil's phagocytic capacity [26] and low copper status results in reduced neutrophil phagocytic capacity [27]. Selenium supplementation decreased somatic cell count (SCC). Sordillo et al. [28] have discussed how selenium, copper and zinc can enhance the function of several immune cells, including 
leucocytes, lymphocytes and neutrophils. Role of iron in immunity is reported by Eisa and Elgebaly [29].

Being components of the anti-oxidant system [18], trace elements prevent oxidative stress. Copper is the essential element in two enzymes that are important for immune competence; copper/zinc-superoxide dismutase and ceruloplasmin [16]. Iron is an essential component of catalase, peroxidase and cytochrome oxidase $[19,30]$. These play important roles in oxidative stress [12,19]. Selenium is an essential part of a family of enzymes called glutathione peroxidases (GSH-Px) and thioredoxin reductases [15] which are important for neutralizing free radicals or oxidants. Zinc and manganese, in addition to copper, are also integral parts of SOD [13,17]. All these neutralize free radicals like peroxides, super oxides or hydroxyl ions.

It is important to note that the concentration of trace elements change under different infections or inflammations. These ion changes reflect changes in cation binding of plasma proteins, and more importantly, alterations in cellular uptake mechanisms [5]. These ionic changes help in preventing infection or disease. In dairy cattle, plasma iron and zinc concentrations are decreased during the acute phase response to immunological challenges [31], whereas plasma copper concentration may increase [32]. During mastitis, increased secretion of lactoferrin in milk, a binding protein, occurs which decreases the amount of available iron for Gram-negative bacterial growth [33]. Trace elements contribute to general health by building body defense mechanisms and improving metabolism and hence their deficiency can predispose to diseases. Zinc is an essential trace element involved in the catalytic, structural and regulatory processes of keratinisation and in general protein metabolism [34]. Consequently, teat canal keratin production is dependent on zinc status [34]. Zinc is important for immune function [21]. There are increased risks of metritis, mastitis, locomotion problems or diarrhoea in calves when zinc or copper levels are either marginal or deficient [35].

Feeding organic zinc may have enhanced resistance to mastitis causing pathogens because of improved skin integrity and keratin lining of the teat canal. Zinc plays role in maintaining structural integrity and health of the hoof and udder $[13,36]$. Like zinc, both copper and manganese are important for keratin formation [13]. This provides udder immunity.

\section{Production}

Trace elements improve growth $[7,8]$ and production $[7,9,10]$. They improve feed intake, digestibility and feed conversion thereby improving production [19,23]. Kinal et al. [37] have reported significantly increased milk production following trace mineral supplementation. Zinc has a catalytic, coactive, or structural role in a wide variety of enzymes that regulate many physiological processes including metabolism and growth [21]. Metalloenzymes of which trace elements are essential part are involved in multiple physiological processes including respiration, carbohydrate and lipid metabolism, antioxidant activities, and collagen formation $[5,13,19]$, thereby favoring body growth and production. Trace elements are also important for hormone synthesis which plays an important role in growth and production [3]. Zinc is involved in hormone secretion and function (somatomedin-c, osteocalcin, testosterone, thyroid hormones, insulin, and growth hormone). Effect of trace elements on growth and milk production has been widely studied [9,34,38-46]. Role of copper in growth is reported by Hesari et al. [8], that of iron by Mohri et al. [47], manganese by Hansen et al. [48], cobalt by Nagabhushana et al. [49] and zinc by Fagari-Nobijari et al [50].

\section{Reproduction}

Trace elements are essential for reproduction [51]. Earlier Manspeaker et al. [52] reported the importance of trace minerals in reproduction in cattle. Rabiee et al. [38] reported higher conception rates with organic trace elements in cattle. Trace minerals are important for reproductive performance in livestock [53] because their supplementation improves reproduction [54]. Studies show that the ovarian activity of ruminants is influenced by mineral deficiency [11]. They are also involved in synthesis of hormones that are important for reproduction. Their deficiency affects both steroid [11] and thyroid [55] hormone production.

Copper and zinc play an important role in regulating progesterone production by luteal cells via involvement of superoxide dismutase [56]. Copper is also involved in steroidogenic enzymes cytochrome $\mathrm{P}_{450}, 17 \alpha$-hydroxylase and cytochrome $\mathrm{P}_{450}$ side-chain cleavage and lysyl oxidase [57]. Zinc is involved in the reorganization of ovarian follicles which are the source of progesterone. This occurs through the involvement of metalloproteinase-2 (MMP-2) enzyme, which is a member of zinc endopeptidase family [58]. Zinc is also involved in the secretion and function of male hormone testosterone through the enzymes that control the arachidonic acid cascade [59,60]. Zinc is essential for thyroid hormone secretion and function. Thus, zinc plays an essential role in sexual development and spermatogenesis. Involvement of manganese in the synthesis and production of oestrogen and progesterone may be due to the fact that it acts as a cofactor in the synthesis of cholesterol, a precursor for steroids, including estrogen and progesterone [39]. Iron also plays an important role in ovarian activity [61]. Positive correlation was reported between serum progesterone level and copper-zinc in cows by Yildiz and Akar [62]. Trace elements are important for reproduction $[38,60]$ also via contributing to the normal health of reproductive organs and reproductive cycles. Selenium is important in normal cattle production systems as its apparent direct link to postpartum uterine involution [6]. Inadequate zinc levels have been associated with 
decreased fertility, abnormal oestrus, and abortions $[63,64]$. Slight decrease in serum levels of zinc and copper may induce or predispose animals to repeat breeding and anoestrus. Organic minerals have a beneficial role to play in the resumption of follicular growth and fertility in dairy cows. Importance of trace elements in reproduction has been widely reported $[11,38,60,64-66]$.

Copper, iron and zinc are all important for thyroid hormones due to their role in synthesis or conversion of thyroid hormones [55]. Copper deficiency impairs secretion of tyrosine hydroxylase and dopamine betaenzyme systems which are both copper containing, in the hypothalamic neurons. This causes inhibition of synthesis of thyroid hormone releasing factor. The copper containing peroxidase enzyme of the thyroid gland impairs thyroid hormone secretion [67]. Iron deficiency lowers thyroid peroxidase (TPO) activity and thereby interferes with iodine metabolism in the thyroid [68]. The $\mathrm{T}_{3}$ receptor is thought to require zinc to adopt its biologically active conformation. Some of the effects of zinc deficiency, therefore, may be due to loss of zinc from the $T_{3}$ receptor and the subsequent impairment of $\mathrm{T}_{3}$ action [69]. The role of selenoproteins in thyroid hormone synthesis is well known [70].

\section{Requirements of trace minerals}

Trace mineral requirements in animals are variable and depend on age [71], sex [72], stage of growth or production $[2,19]$ breed and genotype $[73,74,75]$. They are recommended by different agencies like National Research Council, India [2,19,74], Agricultural Research Council, India [76] or researchers [3,75,77] in both livestock and poultry.

\section{Conclusion}

Trace elements are essential for health, growth, production and reproduction. They are essential for functioning of a number of components of the immune system. Thus, they contribute to maintaining proper health and immunity. They are important for functioning of a number of enzymes and proteins which are involved in many physiological and biochemical processes. These physio-biochemical processes are related to growth, production and reproduction. Hence trace elements affect both the health and production performance of animals.

\section{References}

1. McDowell, L.R. (1992) Minerals in animal and human nutrition. Academic Press Inc. Harcourt Brace Jovanovich Publishers, San Diego, CA.

2. NRC, (1996) Nutrient requirements of beef cattle. $7^{\text {th }}$ Rev. Ed. National Academic Press, Washington, DC.

3. Suttle, N.F. (2010) Mineral Nutrition of Livestock, $4^{\text {th }}$ Edition. CABI Publishing, USA.

4. Radostits, O.M., Gay, C.C., Blood, D.C. and Hinchliff, F.W. (2007) Veterinary Medicine. A text book for the diseases of cattle , sheep, pigs, goats and horses, $10^{\text {th }}$ Ed. Bailliere Tindall, London.
5. Andrieu, S. (2008) Is there a role for organic trace element supplements in transition cow health? Vet. J. 176:77-83.

6. Arthington, J.D. (2005) Trace mineral nutrition and the immune response in cattle. Proc. $64^{\text {th }}$ Annual Minnesota Nutrition Conference. Minneapolis, MN. p. 106.

7. Gressley, T.F. (2009) Zinc, copper, manganese, and selenium in dairy cattle rations. Proceedings of the $7^{\text {th }}$ Annual MidAtlantic Nutrition Conference.

8. Hesari, B.A., Mohri, M. and Seifi, H.A. (2012) Effect of copper edetate injection in dry pregnant cows on hematology, blood metabolites, weight gain and health of calves. Trop. Ani. Health Prod. 44(5): 1041-1047.

9. Siciliano-Jones, J.L., Socha, M.T., Tomlinson, D.J. and De Frain, J.M. (2008) Effect of trace mineral source on lactation performance, claw integrity, and fertility of dairy cattle. $J$. Dairy Sci. 91: 1985-1995.

10. Spears, J.W. and Weiss, W.P. (2008) Role of antioxidants and trace elements in health and immunity of transition dairy cows. Vet. J. 176: 70-76.

11. Boland, M. P. (2003) Trace minerals in production and reproduction in dairy cows. Adv. Dairy Technol. 15:319-330.

12. Antonyuk, S.V., Strange, R.W., Marklund, S.L. and Hasnain, S.S. (2009) The structure of human extracellular copper-zinc superoxide dismutase at $1.7 \mathrm{~A}$ resolution: insights into heparin and collagen binding. J. Mol. Biol. 388 (2):310-26.

13. Tomlinson, D.J., Mulling, C.H. and Fakler, T.M. (2004) Invited review: formation of keratins in the bovine claw: roles of hormones, minerals, and vitamins in functional claw integrity. J. Dairy Sci. 87: 797-809.

14. Rotruck, J.T., Pope, A.L., Ganther, H.E., Swanson, A.B., Hafeman, D.G. and Hoekstra, W.G. (1973) Selenium, biochemical role as a component of glutathione peroxidase. Science. 179: 588-590.

15. Huang, Z., Rose, A.H. and Hoffmann, P.R. (2012) The role of selenium in inflammation and immunity: from molecular mechanisms to therapeutic opportunities. Antioxidants and Redox Signaling. 16(7): 705-743.

16. Hussein, H.A. and Staufenbiel, R. (2012) Variations in copper concentration and ceruloplasmin activity of dairy cows in relation to lactation stages with regard to ceruloplasmin to copper ratios. Biol. Trace Ele. Res. 146(1): 47-52.

17. Markesbery, W.R., Montine, T.J. and Lovell, M.A. (2001) Oxidative alterations in neurodegenerative diseases. In: Mattson, M.P. (Ed.), Pathogenesis Disorders. Humana Press, Totowa, NJ, USA.

18. Spears, J.W. (1995) Improving cattle health through trace mineral supplementation. Range Beef Cow Symposium. Paper 191.

19. NRC, (2001) Nutrient Requirements of Dairy Cattle: 7th Revised Edition. National Academy Press, Washington D.C.

20. Predieri, G., Tegoni, M., Cinti, E., Leonardi, G. and Ferruzza, S. (2003) Metal chelates of 2-hydroxy-4-methylthiobutanoic acid in animal feeding: preliminary investigations on stability and bioavailability. J. Inorg. Biochem. 95:221-224.

21. Vallee, B.L. and Falchuk, K.H. (1993) The biochemical basis of zinc physiology. Physiol. Rev. 73: 79-118.

22. Nemec, L.M., Richards, J.D., Atwell, C.A., Diaz, D.E., Zanton, G.I. and Gressley, T.F. (2012) Immune responses in lactating Holstein cows supplemented with $\mathrm{Cu}, \mathrm{Mn}$, and $\mathrm{Zn}$ as sulfates or methionine hydroxy analogue chelates. $J$. Dairy Sci. 95(8): 4568-77.

23. Close, W.H. (1998) The role of organic trace mineral proteinates in pig nutrition. In: Biotechnology in the Feed Industry. Proc Alltech's 14 ${ }^{\text {th }}$ Annual Symp. pp469-483.

24. Terpiłowska, S. and Siwicki, A.K. (2011) The role of selected microelements: selenium, zinc, chromium and iron in immune system. Centr. Eur. J. Immunol. 36 (4): 303-307.

25. Arthington, J.D. and Havenga, L.J. (2012) Effect of injectable trace minerals on the humoral immune response to multivalent vaccine administration in beef calves. J. Anim. Sci. 90(6): 1966-71. 
26. Sordillo, L. M. (2013) Selenium-dependent regulation of oxidative stress and immunity in periparturient dairy cattle. Vet. Med. Int. 1-8.

27. Cortinhas, C.S., Botaro, B.G., Sucupira, M.C.A., Renno, F.P. and Santos, M.V. (2010) Antioxidant enzymes and somatic cell count in dairy cows fed with organic source of zinc, copper and selenium. Livestock Science, 127(1): 84-87.

28. Sordillo, L.M., Shefer-Weaver, K. and DeRosa, D. (1997) Immunobiology of the mammary gland. J. Dairy Sci. 80: 1851-1865.

29. Eisa, A.M.A. and Elgebaly, L.S. (2010) Effect of ferous sulphate on haematological, biochemical and immunological parameters of neonatal calves. Veterinaria Italiana. 46 (3): 329-335.

30. Harvey, J.W. (2000) Microcytic anemia. In: Feldman BF, Zinkl JG, Jain NC (eds) Schalm's veterinary hematology, 5th edn. Lippincott, Williams and Wilkins, Philadelphia. pp 201-204.

31. Kushner, I. (1982) The phenomenon of the acute phase response. Annals of the New York Academy of Sciences. 389:39-48.

32. Hayes, M.A. (1994) Functions of cytokines and acute phase proteins in inflammation. In: Proceedings of the Seventh Congress of the International Society for Applied Cardiovascular Biology, Guelph, Canada, pp. 1-7.

33. Todhunter, D., Smith, K.L. and Hogan, J.S. (1990) Growth of gram-negative bacteria in dry cow secretion. J. Dairy Sci. 73: 363-372.

34. Wang, R.L., Liang, J.G., Lu, L., Zhang, L.Y., Li, S.F., Luo, X.G. (2013) Effect of zinc source on performance, zinc status, immune response, and rumen fermentation of lactating cows. Biol Trace Elem Res. 152(1): 16-24.

35. Enjalbert, F., Lebreton, P. and Salat, O. (2006) Effects of copper, zinc and selenium status on performance and health in commercial dairy and beef herds: Retrospective study. $J$. Anim. Physiol.Anim. Nutr. 90: 459-466.

36. Tomlinson, D.J., Socha, M.T. and DeFrain, J.M. (2008) Role of trace minerals in the immune system. Page 39-52. In: Proc. Penn State Dairy Cattle Nutrition Workshop. Grantville, PA. Underwood, E.J. and Suttle, N.F. (1999). The Mineral Nutrition of Livestock, $3^{\text {rd }}$ Edition. CABI Publishing, Wallingford, Oxfordshire, pp 614.

37. Kinal, S., Korniewicz, D., Jamroz, D., Korniewicz, A., Slupczynska, M., Bodarski, R., Zieminski, R., Osinglowski, S. and Dymarski, I. (2007) The effectiveness of zinc, copper and manganese applied in organic forms in diets of high milk yielding cows. J. Food, Agri. Envir. 5: 189-193.

38. Rabiee, A.R., Lean, I.J., Stevenson, M.A. and Socha, M.T. (2010) Effects of feeding organic trace minerals on milk production and reproductive performance in lactating dairy cows: a meta-analysis. J. Dairy Sci. 93(9): 4239-51.

39. Karkoodi, K., Chamani, M., Beheshti, M., Mirghaffari, S.S. and Azarfar, A. (2012) Effect of organic zinc, manganese, copper, and selenium chelates on colostrum production and reproductive and lameness indices in adequately supplemented Holstein cows. Biol. Trace Elem. Res. 146(1):42-6.

40. Machadoa, V.S., Bicalhoa, M.L.S., Pereiraa, R.V., Caixetaa, L.S., Knauera, W.A., Oikonomoua, G., Gilbertb, R.O. and Bicalho R.C. (2013) Effect of an injectable trace mineral supplement containing selenium, copper, zinc, and manganese on the health and production of lactating Holstein cows. Vet. J. 197(2): 451-6.

41. Akins, M.S., Bertics, S.J., Socha, M.T. and Shaver, R.D. (2013) Effects of cobalt supplementation and vitamin B12 injections on lactation performance and metabolism of Holstein dairy cows. J. Dairy Sci. 96(3): 1755-68.

42. Sobhanirad, S., Carlson, D. and Bahari Kashani R. (2010) Effect of zinc methionine or zinc sulfate supplementation on milk production and composition of milk in lactating dairy cows. Biol Trace Elem Res. 136(1): 48-54.

43. Cook, J.G. and Green, M.J. (2010) Milk production in early lactation in a dairy herd following supplementation with iodine, selenium and cobalt. Vet Rec.167(20): 788-9.

44. Livesey, C.T. and Payne, J.H. (2010) Supplementation of dairy cows with iodine. Vet Rec. 18: 167(25): 985-986.

45. Heidarpour Bami, M., Mohri, M., Seifi, H.A. and Alavi Tabatabaee, A.A. (2008) Effects of parenteral supply of iron and copper on hematology, weight gain, and health in neonatal dairy calves. Vet. Res. Com. 32: 553-561.

46. Hackbart, K.S., Ferreira, R.M., Dietsche, A.A., Socha, M.T., Shaver, R.D., Wiltbank, M.C. and Fricke, P.M. (2010) Effect of dietary organic zinc, manganese, copper, and cobalt supplementation on milk production, follicular growth, embryo quality, and tissue mineral concentrations in dairy cows. J. Anim. Sci. 88: 3856-3870.

47. Mohri, M., Poorsina, S. and Sedaghat, R. (2010) Effects of parenteral supply of iron on RBC parameters, performance, and health in neonatal dairy calves. Biol Trace Elem Res. 136(1):33-39.

48. Hansen, S.L., Spears, J.W. Whisnant, C.S. and Lloyd. K.E. (2006) Growth, reproductive performance, and manganese status of beef heifers fed varying concentrations of manganese. J. Anim. Sci. 84:3375-3380.

49. Nagabhushana, V., Sharma, K., Pattanaik, A.K. and Dutta, N. (2008) Effect of Cobalt Supplementation on Performance of growing Calves. Vet World. 1(10): 299-302.

50. Fagari-Nobijari, H, Amanlou, H. and Dehghan-Banadaky, M. (2012) Effects of zinc supplementation on growth performance, blood metabolites and lameness in young Holstein bulls. J. Applied Ani. Res. 40(3): 222-228.

51. Chester-Jones, H., Vermeire, D., Brommelsiek, W., Brokken, K., Marx, G. and Linn J. G. (2013) Effect of trace mineral source on reproduction and milk production in Holstein cows. Prof. Ani. Sci. 29: 289-297.

52. Manspeaker, J.E., Robl, M.G., Edwards, G.H. and Douglass, L.W. (1987) Chelated minerals: Their role in bovine fertility. Veterinary Medicine. 82:951-956.

53. Kumar, S., Pandey, A.K., Ahmed, W., Razzaque, A. and Dwivedi, D.K. (2011) Importance of micro minerals in reproductive performance of livestock. Vet World. 4(5): 230233.

54. Grace, N.D. and Knowles, S.O. (2012) Trace Element Supplementation of Livestock in New Zealand: Meeting the Challenges of Free-Range Grazing Systems. Veterinary Medicine International. 12: 1-8.

55. Abdollahi, E. Kohram, H. and Shahir, M.H. (2013) Plasma concentrations of essential trace microminerals and thyroid hormones during single or twin pregnancies in fat-tailed ewes. Small Ruminant Research. 113(2-3): 360-364.

56. Sales, J.N.S. Pereira, R.V.V. Bicalho, R.C. and Baruselli, P.S. (2011) Effect of injectable copper, selenium, zinc and manganese on the pregnancy rate of crossbred heifers (Bos indicus $\times$ Bos taurus) synchronized for timed embryo transfer. Livestock Science. 142(1-3): 59-62.

57. Kendall, N.R., Marsters, P., Guo, L., Scaramuzzi, R.J. and Campbell, B.K. (2006) Effect of copper and thiomolybdates on bovine theca cell differentiation in vitro. J. Endocr. 189: 455-463.

58. Gottsch, M.L., Murdoch, W.J. and Van Kirk, E.A. (2000) Tumour necrosis factor alpha upregulates matrix metalloproteinase-2 activity in preovulatory ovine follicles metamorphic and endocrine implications. Reprod. Fertil. Develop. 12: 75-80.

59. Chanmugam, P., Wheeler, C. and Hwang, D.H. (1984) The effect of zinc deficiency on prostaglandin synthesis in rat testes. J. Nutr. 114: 2066-2072.

60. Ceylan, A., Serin, Ý., Aksit, H. and Seyrek, K. (2008) Concentrations of some elements in dairy cows with reproductive disorders. Bull Vet. Inst. Pulawy. 52: 109-112.

61. Qian, L.C., Zou, X.T., Xu, Z.R. and Xi, S. (2001) Effect of various levels of iron on the reproductive performance and biochemical parameters of gestation cow. Chinese J. Vet. Sci. 21:526-528

62. Yildiz, H. and Akar, Y. (2001) Relationships between serum 
progesterone and some mineral levels during the oestrous cycles in cows. Saglik-Bilimleri-Dergisi-Firatuniversities. 15: 77-84.

63. O'Donoghue, D.G. and Boland, M. (2002) The effect of proteinated trace minerals on fertility and somatic cell counts of dairy cattle. J. Dairy Sci. 78: 248-255.

64. Hidiroglou, M. (1979) Trace element deficiencies and fertility in ruminants: a review. J. Dairy Sci. 62: 1995-2206.

65. Yatoo, M.I., Saxena, A., Kumar, P., Gugjoo, M.B., Dimri, U., Sharma, M.C., Jhambh, R. (2013) Evaluation of serum mineral status and hormone profile in goats and some of their inter-relations. Vet World. 6(6): 318-320.

66. Bedwal, R.S., Bahuguna, A. (1994) Zinc, copper and selenium in reproduction. Experientia. 50: 626-640.

67. Singh, J.L., Sharma, M.C., Kumar, M., Rastogi, S.K., Gupta, G.C., Singh, S.P., Sharma, L.D., Gandhi, V.K. and Kalicharan. (2002) Assessment of therapy in goitrous goat through cardiac function tests. Small Rum. Res. 44: 119-124.

68. Hess, S.Y., Zimmermann, M.B., Arnold, M., Langhans, W. and Hurrell, R.F. (2002) Iron deficiency anemia reduces thyroid peroxidase activity in rats. J. Nutr. 132: 1951-1955.

69. Freake, H.C., Govoni, K.E., Guda, K., Huang, C. and Zinn, S.A. (2001) Actions and interactions of thyroid hormone and zinc status in growing rats. J. Nutr. 131: 1135-41.

70. Hefnawy, A.E.G. and Tórtora-Pérez, J.L. (2010) The importance of selenium and the effects of its deficiency in animal health. Small Rum. Res. 89(2-3): 185-192.

71. Devi, S., Yatoo, M.I., Kumar, P., Tiwari, R. and Sharma, M.C. (2011) Evaluation of micro mineral profile in the growing Vrindhavani cattle. Ind. J. Vet. Med. 31(2): 109-111.

72. Yatoo, M.I., Devi, S., Kumar, P., Tiwari, R. and Sharma, M.C. (2012) Evaluation of micro mineral profile in the growing male and female Vrindhavani cattle. Ind. J. Vet. Med.32(2): 96-98.

73. Lukić, M., Pavlovski, Z. and Škrbić, Z. (2009) Mineral nutrition of modern poultry genotypes. Biotechnology in Animal Husbandry. 25(5-6): 399-409.

74. NRC, (1994) Mineral requirements of poultry. $9^{\text {th }}$ Edition. National Academy of Science, Washington DC.

75. Waldroup, P.W. (2001) Dietary nutrient allowances for chickens and turkeys. Feedstuffs. 73(29): 56-65.

76. ARC, (1980) Nutrient requirements of ruminants. Commonwealth Agricultural Bureaux, Farnham Royal UK, pp 184-185.

77. Chiba, L.I. (2009) Poultry Nutrition and Feeding Section 12. Animal Nutrition Handbook. pp 316-333.

$* * * * * * * *$ 